\title{
Dilemma of HCV Infection in Renal Transplant Recipients
}

\author{
Osama Ashry Ahmed Gheith \\ Urology and Nephrology Center, Mansoura University, Gomhoria Street, Mansoura, Egypt \\ Correspondence should be addressed to Osama Ashry Ahmed Gheith, ogheith@yahoo.com
}

Received 14 November 2010; Revised 19 January 2011; Accepted 5 March 2011

Academic Editor: Ayman Karkar

Copyright (C) 2011 Osama Ashry Ahmed Gheith. This is an open access article distributed under the Creative Commons Attribution License, which permits unrestricted use, distribution, and reproduction in any medium, provided the original work is properly cited.

\begin{abstract}
Hepatitis C virus, which usually starts during dialysis therapy, is currently the main cause of chronic liver disease in such population. The majority of patients acquired the disease through intravenous drug use or blood transfusion, with some risk factors identified. In this review we are dealing with the effect of renal transplantation on HCV infection and HCV-related complications after renal transplantation. Moreover, we are discussing the therapeutic options of HCV infection before and after renal transplantation, the best immunosuppressive protocol and lastly graft and patient survival in patients who underwent pretransplant management vs. those who were transplanted without treatment.
\end{abstract}

\section{Introduction}

Liver disease is one of the leading causes of death in longterm renal transplant survivors $[1,2]$, and hepatitis $C$ virus (HCV) is currently the main cause of chronic liver disease in such population [1-7]. Hemodialysis patients represent a high-risk group for $\mathrm{HCV}$ infection, possibly due to a direct or indirect exposure to contaminated blood [6]. Although HCV infection may be transmitted through transplantation itself $[1,8]$, it usually starts during dialysis therapy $[1-4]$.

\section{HCV Genotypes and Prevalence}

Worldwide, at least 6 major genotypes of the HCV have been identified, each comprising multiple subtypes [9-13]. Genotypes 1, 2, and 3 have a worldwide distribution, while their relative prevalence varies from one geographic area to another. Hepatitis $\mathrm{C}$ virus subtypes $1 \mathrm{a}$ and $2 \mathrm{~b}$ are the most common genotypes in the United States and Europe [14-16]. Subtype $1 \mathrm{~b}$ is responsible for up to $73 \%$ of HCV infection in Japan [17]. Subtypes $2 \mathrm{a}$ and $2 \mathrm{~b}$ are relatively common in North America, Europe, and Japan, while $2 \mathrm{c}$ is found commonly in Northern Italy. Intravenous drug abusers in Europe and the United States have the HCV genotype 3a [18]. Genotype 4 appears to be prevalent in North Africa and the Middle East while genotypes 5 and 6 in South Africa and Hong Kong [10-12].

\section{Transmission}

The majority of HCV infected patients acquired the disease through intravenous drug use or blood transfusion, with the following risk factors identified [13]: intravenous drug use, blood transfusion, sex with an intravenous drug user, having been struck or cut with a bloody object, pierced ears or body parts, and immunoglobulin injection. Other risk factors identified among dialysis patients included blood transfusions, the duration of end-stage renal disease (and dialysis), the type of dialysis (risk is the highest with in-hospital hemodialysis especially with lack of adherence to universal precautions and the lowest with peritoneal dialysis), and the prevalence of HCV infection in the dialysis unit.

\section{Diagnostic Approach to Hepatitis C Virus Infection}

HCV RNA testing should be performed in those with a positive antibody test, especially when antiviral treatment is being considered, and in those with unexplained liver disease and negative anti-HCV test especially who are immunocompromised or suspected of having acute $\mathrm{HCV}$ infection. HCV genotype should be determined in all infected persons prior to treatment to determine the duration of therapy and the likelihood of response [19]. 
Absence of HCV RNA despite anti-HCV antibodies may be seen in a number of circumstances especially with false positive results on antibody tests due to technical reasons, anti-HCV antibodies that have been passively acquired from blood transfusions, maternal antiHCV antibodies in babies; intermittent viremia, HCV sequestration at sites other than the blood stream and the number of copies of HCV RNA below the limit of detection and in immunocompromised patients [14, $15]$.

\section{Effect of Renal Transplantation on HCV Infection}

Renal transplantation guidelines $[5,6]$ recommend that all transplant candidates should be evaluated for $\mathrm{HCV}$ infection; positive anti-HCV antibodies by immunoassay (EIA) require confirmation by HCV RNA determination. Most EIA positive patients have detectable HCV RNA in their sera. This viremic state continues in most of transplant recipients. Chronic liver disease after renal transplantation depends on many risk factors such as the pretransplant duration and the severity of $\mathrm{HCV}$ infection, the liver histopathology, the coinfection with hepatitis B virus, the duration after transplantation and the type of induction and maintenance immunosuppression [1-5]. However, some studies $[20,21]$ showed that antibody induction had no negative impact on patient survival. The viral load increases up to 30 times compared to levels before transplantation in HCV RNA-positive patients, suggesting the role of immunosuppressive regarding this issue $[16,17]$. Mycophenolate mofetil [18] and antithymocyte globulin [1] increase HCV viremia while cyclosporin inhibits the replication of HCV in cultured hepatocytes [22]. It is worth mentioning that HCV-RNA titers do not differ between patients with or without posttransplant liver disease [1] and are not clearly related to liver disease progression [23]. Apart from cases with fibrosing cholestatic hepatitis [24], HCV infection after renal transplantation usually has a benign course $[4,5,25]$, with normal transaminases in $20-51 \%$ of cases [4]. In a meta-analysis, cause-specific mortality due to liver disease (cirrhosis or hepatocellular carcinoma (HCC)) in HCV-infected kidney transplant recipients was increased in most of the studies, with a $\mathrm{RR}$ of death of 1.79 , compared to HCV-negative cases [20].

Liver biopsies in cases with chronic elevation of transaminases have documented severe liver disease, for example, chronic active hepatitis or cirrhosis, in up to $20 \%$ of HCV-positive transplant recipients [4]. Zylberberg et al. [21] described a faster progression of the liver histological activity and fibrosis in kidney transplant patients than in non-immunocompromised patients infected by $\mathrm{HCV}$ although Alric et al. [23] observed a slow progression of liver fibrosis in HCV-infected kidney transplant patients, a finding which was also inferior to that observed in infected patients with a normal renal function. The use of different immunosuppressive protocols might explain these discrepancies.

\section{Therapeutic Options of HCV Infection and Kidney Transplantation}

The problem of anti-HCV therapy is that interferon (IFN) has been associated with an increased risk of allograft rejection not only in the functioning grafts but also in the already failed grafts $[26,27]$. Therefore this may explain the major hesitancy to the use of IFNa in renal transplant recipients [12]. It increases rejection possibly by cytokine gene expression, increased cell surface expression of HLA antigens, and enhanced function of natural killer cells, cytotoxic T cells, and monocytes. These immune-stimulant effects can result in enhanced allograft rejection-which may be irreversible-even in patients with stable grafts $[28,29]$. So it has been indicated only in patients with fibrosing cholestatic hepatitis $[3,30,31]$ or other conditions in which the benefits of treatment outweigh the risk of allograft loss. There are extremely limited data evaluating the efficacy and complications of IFNa therapy in the treatment of possible HCV-related cryoglobulinemia or de novo or recurrent glomerular disease in renal transplant recipients $[28,29]$. Pageaux et al. [32] showed that treatment of HCV with IFN after transplantation might not be as risky as initially shown. Posttransplant monotherapies with ribavirin and/or amantadine have no apparent impact on $\mathrm{HCV}$ viremia or liver histology [30].

So the best strategy is to treat HCV infection in patients on dialysis before transplantation [2, 3, 6, 7, 33-37] after excluding cirrhosis by liver biopsy and if present patients should be considered for combined kidney-liver transplantation. Such strategy could prevent liver disease progression [30] and even HCV-related morbidities such as glomerulonephritis [34] and posttransplant diabetes mellitus [29]. IFN-based therapy should be offered to patients with an active viral infection (HCV RNA positive) and a biopsyproven chronic hepatitis. Liu demonstrated the superior efficacy and safety profile of pegylated-IFN as compared with standard-IFN on dialysis-treated patients [38]. Using multivariate analysis, pegylated-IFN was independently predictive of sustained virological response (SVR). Combined therapy with pegylated-IFN and low-dose ribavirin achieved SVR in most of patients enrolled in the study [39], but the majority of cases $(74 \%)$ developed severe anemia. Therefore, the treatment would consist of standard-IFN, 3 million units three times a week for 48 weeks for genotypes 1 and 4 , and 24 weeks for genotypes 2 and 3. This treatment achieves SVR in around $40 \%$ of treated patients $[26,40]$.

\section{HCV-Related Complications after Renal Transplantation}

7.1. Glomerular Lesions. The most frequent glomerular lesions observed among HCV-positive kidney transplant recipients are cryoglobulinaemic or noncryoglobulinaemic membranoproliferative glomerulonephritis (MPGN) [41, 42] and membranous glomerulonephritis (MGN) [43]. Transplant glomerulopathy [2], anticardiolipin-related thrombotic microangiopathy [44], and fibrillary glomerulonephritis [45] have also been described. The pathogenesis of MPGN 
and MGN seems to be due to deposition of immune complexes containing viral RNA in the glomerulus $[2,46]$, as viral antigens have been detected by immunohistochemistry [47].

HCV-associated glomerulonephritis has been postulated to be due to abnormality in Toll-like receptor-proteins expressed on immune and nonimmune cells as important components of the innate immunity-because Wörnle et al. [48] found that these receptors were elevated in the mesangial cells in HCV-related glomerulonephritis and was associated with enhanced proinflammatory cytokines. Till now there is no specific therapy for the treatment of $\mathrm{HCV}$ - related glomerular lesions after renal transplantation. However, rituximab, an anti-CD20 antibody that targets B cells, has been effective in some cases of HCV-related posttransplant cryoglobulinemia. Pérez-Calvo et al. in [49] had evaluated its safety in HCV-positive patients, and they concluded that it is a promising treatment modality for HCV-associated extra-hepatic disorders [49].

7.2. Posttransplant Diabetes Mellitus (PTDM). The diagnosis of hyperglycemia should be according to current American Diabetes Association (ADA) criteria (fasting blood glucose $>125 \mathrm{mg} / 100 \mathrm{~mL}$ on two separate measures). Lastly, patients with PTDM should be referred to a diabetologist [6]. HCV infection seems to be related to a higher incidence of diabetes mellitus [2]. In a meta-analysis of 13 observational studies including more than 30000 renal transplant patients, Fabrizi et al. [50] found significant increase in the risk of PTDM in HCV-positive patients. Moreover, tacrolimus in HCV-infected patients has been described to increase the incidence of PTDM [50, 51], which may be one of the risk factors explaining a lower patient and graft survival among HCV-positive patients [6]. Insulin resistance caused by inhibitory actions of the virus on hepatic insulin regulatory pathways [52] in addition to an overexposure to tacrolimus, especially during the first days after transplantation, represented the main mechanisms. Moreover, HCV replication probably slows down tacrolimus metabolism [53, 54]. So optimization of immunosuppressive agents that are clearly associated with PTDM should be balanced to get their antirejection efficacy, while minimizing the risk of hyperglycaemia, as 2008 KDIGO guidelines recommended [6].

7.3. Acute Rejection. The issue whether HCV infection decreases or enhances the risk of acute rejection is still a controversial. HCV induces a state of immunodeficiency, based on a reduction in the rate of naïve T-helper lymphocytes and an alteration in the proliferative responses to mitogens of $\mathrm{T}$ lymphocytes [55], which might explain a decreased incidence of acute rejection [1-3]. On the other hand, a similar $[8,56]$ or even a higher incidence of acute rejection was observed in $\mathrm{HCV}$-positive patients [57], possibly due to longer history of renal disease, previous transplants, and blood transfusions, which are all risk factors for HCV infection in kidney transplant recipients. Forman et al. [57] observed a higher incidence of antibody-mediated acute rejection in their cohort of HCV-positive patients.
In a Spanish series of 435 kidney transplant cases with a protocol biopsy performed during the first 6 months after transplantation, they concluded that subclinical acute rejection with chronic allograft nephropathy and hepatitis $\mathrm{C}$ infection were both independent risk factors for graft loss [58]. From that study, Serón et al. [59] showed that graft survival improved during this decade despite worsening of renal quality (elderly donors) and poorer HLA matching (higher HLA mismatches). They attributed these findings to the decrease of the prevalence of HCV infection (from 29\% to $10 \% ; P<.0001$ ) and acute rejection (from $39 \%$ to $25 \%$; $P<.0001)$.

7.4. Posttransplant Tuberculosis. Torres et al. [60] reported that $\mathrm{HCV}$ infection is the most important risk factor for the development of tuberculosis in renal transplant patients. Therefore, a careful immunosuppressive regimen should be selected in these patients. We suggest-in immunologically low-risk patients-either rapamycin-based or cyclosporine based protocols to be used without steroids. On the other hand, it will be difficult to find the ideal immunosuppressive strategy for $\mathrm{HCV}$-positive patients with immunological high risk.

7.5. Malignancies. After organ transplantation HCV infection has been added to the well-known risk factors of posttransplant lymphoproliferative disorders (PTLDs) such as Epstein-Barr virus, induction and antirejection therapies. The overall prevalence is $(0.8 \%)$ in renal transplant recipients and is significantly higher in HCV-positive $(3.6 \%)$ than in HCV-negative patients (1.2\%) [61]. Moreover, in a study from Taiwan, PTLD was the second cause of posttransplant neoplasia in HCV-positive recipients [62]. In the American Registry including 66169 recipients, the incidence of HCV infection was higher in myeloma patients, suggesting a possible association between $\mathrm{HCV}$ infection and myeloma [63].

\section{Patient Survival after Kidney Transplantation among HCV Infected Patients}

It is reported that the survival of HCV-positive patients after renal transplantation is significantly better than that of matched patients who remain on dialysis $[10,64,65]$. However, HCV-positive patients after renal transplantation have a lower patient and graft survival compared to HCVnegative patients $[5-12,20,66,67]$. In the short-term followup, HCV infection after renal transplantation showed similar survival as compared to noninfected renal transplant recipients [52]. But in the majority of long-term studies, HCV-positive patients have a significantly lower survival than HCV-negative patients $[3,10-12,20,66]$. abdulkarim et al. [11] found that 10-year patient survival was significantly lower in HCV-positive patients: $65.5 \%$ versus $85.3 \%$ $(P<.001)$. Moreover, the multivariate analysis showed that among HCV-positive renal transplant cases, biopsy-proven cirrhosis, age, and duration of transplantation were independent risk factors for 10 -year patient survival and $21 \%$ of deaths were caused by liver disease in HCV-positive patients. 
In a Spanish multicenter study with $488 \mathrm{HCV}$-positive cases out of a total population of 3,365 patients transplanted between 1990 and 1998, they concluded that HCV infection was an independent risk factor for patient death and mortality rate due to liver disease was higher than that in $\mathrm{HCV}$-negative patients $(13.85 \%$ versus $0.6 \% ; P=.03$ ) [8] and it was progressively increasing by time $(10 \%$ at 10 years and $20 \%$ at 20 years) [9]. Similar findings were concluded in a meta-analysis including other observational studies by Fabrizi et al. [20]. This was partially related to an increase in liver-related deaths and the higher frequency of both hepatic and extrahepatic complications in HCVpositive as compared to HCV-negative recipients [66]. Heavy immunosuppression, probably, increases the risk of $\mathrm{HCV}$ viral replication after renal transplantation especially with the use of quadruple therapy with monoclonal or polyclonal antibodies [1].

On the other hand, Luan et al. [68] reported that antibody induction did not negatively affect patient survival with HCV infection. Therefore, all conventional current immunosuppressive drugs can be used in HCV-positive patients [6]. It is worth mentioning that cyclosporine inhibits $\mathrm{HCV}$ viral replication in cultured hepatocytes [69] and this supported clinical findings that HCV-positive renal transplant recipients under cyclosporine immunosuppression showed stabilization and regression of liver fibrosis in more than $50 \%$ of patients [23]. The risk of PTDM is higher in HCV-positive patients treated with tacrolimus [51], which can be minimized by low-dose tacrolimus combined with MMF, together with an early steroid withdrawal. Notably, mycophenolate mofetil as part of maintenance immunosuppressive regimen was associated with better patient survival [68]. The influence of m-TOR inhibitors (sirolimus and everolimus) on patient survival after renal transplantation is unknown.

\section{Influence of HCV Infection on Graft Survival}

HCV infection did not adversely affect short-term graft survival [51] but exhibited lower long-term graft survival compared to HCV-negative patients $[8,10-12,20,66]$. Several studies showed that HCV infection was an independent risk factor for graft loss $[7,9,11,12,20,66-71]$. In a meta-analysis including 6345 patients, the presence of anti-HCV-positive antibodies was an independent and significant factor for graft failure (RR 1.56, 95\% CI 1.35$1.80, P=.019)$ in four of the eight studies included in the analysis. The mechanisms might be due to development of proteinuria because of chronic allograft nephropathy and/or $\mathrm{HCV}$-associated glomerulonephritis and PTDM. HCV infection is an independent risk factor for proteinuria after transplantation. Hestin et al. [56] reported that persistent proteinuria developed more frequently in $\mathrm{HCV}$-positive than in $\mathrm{HCV}$-negative patients. The probability of proteinuria increases from $19.5 \%$ in the $\mathrm{HCV}$-positive versus $7.5 \%$ in HCV-negative patients at 1 year to $22.9 \%$ versus $10.7 \%$ at 3 years to $45.1 \%$ versus $13.1 \%$, respectively, at 5 years. Cosio et al. [72] found that the prevalence of HCV antibodies was significantly higher in patients with chronic transplant glomerulopathy (33\% in HCV-positive cases versus $1.9 \%$ in negative cases, resp., $P=.0004$ ) and so they extrapolated that HCV may produce endothelial cell lesion leading to transplant glomerulopathy. In another study done in Mansoura, Egypt by Mahmoud et al. [70] they also found a higher incidence of proteinuria and chronic rejection in a series of $\mathrm{HCV}$-positive kidney transplant recipients with $\mathrm{HCV}$ RNA in the serum. Notably, absence of IFN therapy before transplantation was a significant risk factor for chronic allograft nephropathy. Posttransplant cryoglobulinemic or noncryoglobulinemic MPGN and MGN associated with HCV infection contribute to the development of graft failure [41-43]. Type I MPGN has been reported to result in accelerated loss of the graft $[41,42]$, while, in MGN, the clinical course and the development of renal failure seem to be similar in patients with and without HCV infection [70].

Another issue is the use of kidneys from HCV-positive donors, a procedure which must not be used in antiHCV-negative recipients (HCVRs) [62]. However, its use into HCVR+ is still a matter of debate [3]. Some authors considered that the approach was appropriate as the outcome after renal transplantation for such patients was better than remaining on dialysis [73]. Moreover, mid-term outcome of these patients was similar to that of HCVR+ transplanted from HCVD-, in terms of patient and graft survival and HCV-related liver disease [74]. Hence, it can be a safe strategy to overcome organ shortage for transplantation, but longterm assessment is still needed $[6,7,75]$.

\section{Conclusions}

Hepatitis $\mathrm{C}$ virus infection is the most frequent cause of liver disease after renal transplantation; although it has no impact on short-term outcome, it adversely affects long-term survival of both graft and patient. Most of the patients with sustained virological response remain so after transplantation with decreased HCV-related posttransplant morbidity. Nonresponsive HCV-positive patients or who refused interferon therapy may be transplanted with optimization of their immunosuppression because of better survival than dialysis.

\section{References}

[1] B. J. Pereira, S. N. Natov, B. A. Bouthot et al., "Effects of hepatitis $\mathrm{C}$ infection and renal transplantation on survival in end-stage renal disease," Kidney International, vol. 53, 1374 pages, 1998.

[2] D. Roth, "Hepatitis C virus: the nephrologist's view," American Journal of Kidney Diseases, vol. 25, no. 1, pp. 3-16, 1995.

[3] J. M. Morales and J. M. Campistol, "Transplantation in the patient with hepatitis C," Journal of the American Society of Nephrology, vol. 11, no. 7, pp. 1343-1353, 2000.

[4] G. G. Vosnides, "Hepatitis C in renal transplantation," Kidney International, vol. 52, no. 3, pp. 843-861, 1997.

[5] "European best practice guidelines for renal transplantation (part 1). Section I: evaluation, selection and preparation of the potential recipient," Nephrology Dialysis Transplantation, vol. 15 , supplement 7, pp. 1-85, 2000.

[6] "KDIGO clinical practice guidelines for the prevention, diagnosis, evaluation, and treatment of hepatitis $\mathrm{C}$ in chronic 
kidney disease," Kidney International, vol. 73, supplement 109, pp. S1-S99, 2008.

[7] A. Covic, D. Abramowicz, A. Bruchfeld et al., "Endorsement of the Kidney Disease Improving Global Outcomes (KDIGO) hepatitis C guidelines: a European Renal Best Practice (ERBP) position statement," Nephrology Dialysis Transplantation, vol. 24, no. 3, pp. 719-727, 2009.

[8] J. M. Morales, B. Domínguez-Gil, D. Sanz-Guajardo, J. Fernández, and F. Escuin, "The influence of hepatitis B and hepatitis $\mathrm{C}$ virus infection in the recipient on late renal allograft failure," Nephrology Dialysis Transplantation, vol. 19, supplement 3, pp. iii72-iii76, 2004.

[9] J. Juszczyk, "Fifteen years of investigations on hepatitis C virus in Poland," Przegląd epidemiologiczny, vol. 59, no. 2, pp. 373384, 2005.

[10] N. N. Zein, "Clinical significance of hepatitis $\mathrm{C}$ virus genotypes," Clinical Microbiology Reviews, vol. 13, no. 2, pp. 223 235, 2000.

[11] A. S. Abdulkarim, N. N. Zein, J. J. Germer et al., "Hepatitis $\mathrm{C}$ virus genotypes and hepatitis $\mathrm{G}$ virus in hemodialysis patients from Syria: identification of two novel hepatitis $\mathrm{C}$ virus subtypes," American Journal of Tropical Medicine and Hygiene, vol. 59, no. 4, pp. 571-576, 1998.

[12] R. W. Chamberlain, N. Adams, A. A. Saeed, P. Simmonds, and R. M. Elliott, "Complete nucleotide sequence of a type 4 hepatitis $\mathrm{C}$ virus variant, the predominant genotype in the Middle East," Journal of General Virology, vol. 78, no. 6, pp. 1341-1347, 1997.

[13] E. L. Murphy, S. M. Bryzman, S. A. Glynn et al., "Risk factors for hepatitis C virus infection in United States blood donors," Hepatology, vol. 31, no. 3, pp. 756-762, 2000.

[14] B. J. Pereira and A. S. Levey, "Hepatitis C virus infection in dialysis and renal transplantation," Kidney International, vol. 51, no. 4, pp. 981-999, 1997.

[15] J. Y. Lau, G. L. Davis, M. E. Brunson et al., "Hepatitis C virus infection in kidney transplant recipients," Hepatology, vol. 18, no. 5, pp. 1027-1031, 1993.

[16] B. J. Pereira, S. N. Natov, B. A. Bouthot et al., "Effect of hepatitis $\mathrm{C}$ infection and renal transplantation on survival in end-stage renal disease. The New England Organ Bank Hepatitis C Study Group," Kidney International, vol. 53, no. 5, pp. 1374-1381, 1998.

[17] D. Roth, K. Zucker, R. Cirocco et al., "A prospective study of hepatitis C virus infection in renal allograft recipients," Transplantation, vol. 61, no. 6, pp. 886-889, 1996.

[18] L. Rostaing, J. Izopet, K. Sandres, J. M. Cisterne, J. Puel, and D. Durand, "Changes in hepatitis C virus RNA viremia concentrations in long-term renal transplant patients after introduction of mycophenolate mofetil," Transplantation, vol. 69, no. 5, pp. 991-994, 2000.

[19] D. B. Strader, T. Wright, D. L. Thomas, and L. B. Seeff, "Diagnosis, management, and treatment of hepatitis C," Hepatology, vol. 39, no. 4, pp. 1147-1171, 2004.

[20] F. Fabrizi, P. Martin, V. Dixit, S. Bunnapradist, and G. Dulai, "Hepatitis $\mathrm{C}$ virus antibody status and survival after renal transplantation: meta-analysis of observational studies," American Journal of Transplantation, vol. 5, no. 6, pp. 14521461, 2005.

[21] H. Zylberberg, B. Nalpas, F. Carnot et al., "Severe evolution of chronic hepatitis $\mathrm{C}$ in renal transplantation: a case control study," Nephrology Dialysis Transplantation, vol. 17, no. 1, pp. 129-133, 2002.

[22] K. Watashi, M. Hijikata, M. Hosaka, M. Yamaji, and K. Shimotohno, "Cyclosporin A suppresses replication of hepatitis
C virus genome in cultured hepatocytes," Hepatology, vol. 38, no. 5, pp. 1282-1288, 2003.

[23] L. Alric, V. Di-Martino, J. Selves et al., "Long-term impact of renal transplantation on liver fibrosis during hepatitis $\mathrm{C}$ virus infection," Gastroenterology, vol. 123, no. 5, pp. 1494-1499, 2002.

[24] E. Muñoz De Bustillo, C. Ibarrola, F. Colina et al., "Fibrosing cholestatic hepatitis in hepatitis $C$ virus-infected renal transplant recipients," Journal of the American Society of Nephrology, vol. 9, no. 6, pp. 1109-1113, 1998.

[25] J. M. Morales, J. M. Campistol, A. Andrés, and J. L. Rodicio, "Hepatitis C virus and renal transplantation," Current Opinion in Nephrology and Hypertension, vol. 7, no. 2, pp. 177-183, 1998.

[26] H. Wéclawiack, N. Kamar, M. Mehrenberger et al., "Alphainterferon therapy for chronic hepatitis $\mathrm{C}$ may induce acute allograft rejection in kidney transplant patients with failed allografts," Nephrology Dialysis Transplantation, vol. 23, no. 3, pp. 1043-1047, 2008.

[27] S. J. Carbognin, N. M. Solomon, F. E. Yeo et al., "Acute renal allograft rejection following pegylated IFN-alpha treatment for chronic HCV in a repeat allograft recipient on hemodialysis: a case report," American Journal of Transplantation, vol. 6, no. 7, pp. 1746-1751, 2006.

[28] O. Ozgur, S. Boyacioglu, H. Telatar, and M. Haberal, "Recombinant alpha-interferon in renal allograft recipients with chronic hepatitis C," Nephrology Dialysis Transplantation, vol. 10, no. 11, pp. 2104-2106, 1995.

[29] Y. Harihara, Y. Kurooka, T. Yanagisawa, K. Kuzuhara, O. Otsubo, and H. Kumada, "Interferon therapy in renal allograft recipients with chronic hepatitis C," Transplantation Proceedings, vol. 26, no. 4, p. 2075, 1994.

[30] N. Kamar, D. Ribes, J. Izopet, and L. Rostaing, “Treatment of hepatitis $\mathrm{C}$ virus infection ( $\mathrm{HCV}$ ) after renal transplantation: implications for HCV-positive dialysis patients awaiting a kidney transplant," Transplantation, vol. 82, no. 7, pp. 853856, 2006.

[31] F. Fabrizi, G. Lunghi, V. Dixit, and P. Martin, "Meta-analysis: anti-viral therapy of hepatitis $C$ virus-related liver disease in renal transplant patients," Alimentary Pharmacology and Therapeutics, vol. 24, no. 10, pp. 1413-1422, 2006.

[32] G. P. Pageaux, M. N. Hilleret, V. Garrigues et al., "Pegylated interferon-alpha-based treatment for chronic hepatitis $\mathrm{C}$ in renal transplant recipients: an open pilot study," Transplant International, vol. 22, no. 5, pp. 562-567, 2009.

[33] G. Barril, E. González Parra, and R. Alcázar, "Guías sobre enfermedades víricas en hemodiálisis,” Nefrología, vol. 24, supplement 2, p. 43, 2004.

[34] J. M. Cruzado, T. Casanovas-Taltavull, J. Torras, C. Baliellas, S. Gil-Vernet, and J. M. Grinyó, "Pretransplant interferon prevents hepatitis $\mathrm{C}$ virus-associated glomerulonephritis in renal allografts by HCV-RNA clearance," American Journal of Transplantation, vol. 3, no. 3, pp. 357-360, 2003.

[35] J. M. Campistol, N. Esforzado, and J. M. Morales, "Hepatitis C virus-positive patients on the waiting list for transplantation," Seminars in Nephrology, vol. 22, no. 4, pp. 361-364, 2002.

[36] L. Rostaing, E. Chatelut, J. L. Payen et al., "Pharmacokinetics of alpha IFN-2b in chronic hepatitis $\mathrm{C}$ virus patients undergoing chronic hemodialysis or with normal renal function: clinical implications," Journal of the American Society of Nephrology, vol. 9, no. 12, pp. 2344-2348, 1998.

[37] N. Kamar, O. Toupance, M. Buchler et al., "Evidence that clearance of hepatitis $\mathrm{C}$ virus RNA after alpha-interferon therapy in dialysis patients is sustained after renal transplantation," 
Journal of the American Society of Nephrology, vol. 14, no. 8, pp. 2092-2098, 2003.

[38] C. H. Liu, C. C. Liang, J. W. Lin et al., "Pegylated interferon alpha-2a versus standard interferon alpha-2a for treatmentnaive dialysis patients with chronic hepatitis $\mathrm{C}$ : a randomised study," Gut, vol. 57, no. 4, pp. 525-530, 2008.

[39] M. Rendina, A. Schena, N. M. Castellaneta et al., "The treatment of chronic hepatitis $\mathrm{C}$ with peginterferon alfa-2a $(40 \mathrm{kDa})$ plus ribavirin in haemodialysed patients awaiting renal transplant," Journal of Hepatology, vol. 46, no. 5, pp. 768774, 2007.

[40] M. W. Russo, C. D. Goldsweig, I. M. Jacobson, and R. S. Brown Jr., "Interferon monotherapy for dialysis patients with chronic hepatitis C: an analysis of the literature on efficacy and safety," American Journal of Gastroenterology, vol. 98, no. 7, pp. 1610 1615, 2003.

[41] J. M. Cruzado, S. Gil-Vernet, G. Ercilla et al., "Hepatitis $\mathrm{C}$ virus-associated membranoproliferative glomerulonephritis in renal allografts," Journal of the American Society of Nephrology, vol. 7, no. 11, pp. 2469-2475, 1996.

[42] D. Roth, R. Cirocco, K. Zucker et al., "De novo membranoproliferative glomerulonephritis in hepatitis C virusinfected renal allograft recipients," Transplantation, vol. 59, no. 12, pp. 1676-1682, 1995.

[43] J. M. Morales, J. Pascual-Capdevila, J. M. Campistol et al., "Membranous glomerulonephritis associated with hepatitis C virus infection in renal transplant patients," Transplantation, vol. 63, no. 11, pp. 1634-1639, 1997.

[44] S. Baid, M. Pascual, W. W. Williams Jr. et al., "Renal thrombotic microangiopathy associated with anticardiolipin antibodies in hepatitis C-positive renal allograft recipients," Journal of the American Society of Nephrology, vol. 10, no. 1, pp. 146-153, 1999.

[45] G. S. Markowitz, J. T. Cheng, R. B. Colvin, W. M. Trebbin, and V. D. D'Agati, "Hepatitis C viral infection is associated with fibrillary glomerulonephritis and immunotactoid glomerulopathy," Journal of the American Society of Nephrology, vol. 9, no. 12 , pp. 2244-2252, 1998.

[46] N. Perico, D. Cattaneo, B. Bikbov, and G. Remuzzi, "Hepatitis $\mathrm{C}$ infection and chronic renal diseases," Clinical Journal of the American Society of Nephrology, vol. 4, no. 1, pp. 207-220, 2009.

[47] K. Kasuno, T. Ono, A. Matsumori et al., "Hepatitis C virus-associated tubulointerstitial injury," American Journal of Kidney Diseases, vol. 41, no. 4, pp. 767-775, 2003.

[48] M. Wörnle, H. Schmid, B. Banas et al., "Novel role of tolllike receptor 3 in hepatitis C-associated glomerulonephritis," American Journal of Pathology, vol. 168, no. 2, pp. 370-385, 2006.

[49] J. Pérez-Calvo, N. Murashige, M. A. Fuertes et al., "The safety of rituximab in hepatitis C virus (HCV) positive patients," Journal of Applied Research, vol. 4, no. 3, pp. 470-475, 2004.

[50] F. Fabrizi, P. Messa, P. Martin, and B. Takkouche, "Hepatitis $\mathrm{C}$ virus infection and post-transplant diabetes mellitus among renal transplant patients: a meta-analysis," International Journal of Artificial Organs, vol. 31, no. 8, pp. 675-682, 2008.

[51] R. D. Bloom, V. Rao, F. Weng, R. A. Grossman, D. Cohen, and K. C. Mange, "Association of hepatitis C with posttransplant diabetes in renal transplant patients on tacrolimus," Journal of the American Society of Nephrology, vol. 13, no. 5, pp. 13741380, 2002.

[52] R. D. Bloom, G. Sayer, K. Fa, S. Constantinescu, P. Abt, and K. R. Reddy, "Outcome of hepatitis C virus-infected kidney transplant candidates who remain on the waiting list,"
American Journal of Transplantation, vol. 5, no. 1, pp. 139-144, 2005.

[53] R. D. Bloom and J. R. Lake, "Emerging issues in hepatitis C virus-positive liver and kidney transplant recipients," American Journal of Transplantation, vol. 6, no. 10, pp. 2232-2237, 2006.

[54] C. Manzanares, M. Moreno, F. Castellanos et al., "Influence of hepatitis C virus infection on FK 506 blood levels in renal transplant patients," Transplantation Proceedings, vol. 30, no. 4, pp. 1264-1265, 1998.

[55] A. Corell, J. M. Morales, A. Mandroño et al., "Immunosuppression induced by hepatitis $\mathrm{C}$ virus infection reduces acute renal-transplant rejection," Lancet, vol. 346, no. 8988, pp. 1497-1498, 1995.

[56] D. Hestin, F. Guillemin, N. Castin, A. Le Faou, J. Champigneulles, and M. Kessler, "Pretransplant hepatitis $C$ virus infection: a predictor of proteinuria after renal transplantation," Transplantation, vol. 65, no. 5, pp. 741-744, 1998.

[57] J. P. Forman, N. Tolkoff-Rubin, M. Pascual, and J. Lin, "Hepatitis C, acute humoral rejection, and renal allograft survival," Journal of the American Society of Nephrology, vol. 15, no. 12, pp. 3249-3255, 2004.

[58] F. Moreso, M. Ibernon, M. Gomà et al., "Subclinical rejection associated with chronic allograft nephropathy in protocol biopsies as a risk factor for late graft loss," American Journal of Transplantation, vol. 6, no. 4, pp. 747-752, 2006.

[59] D. Serón, M. Arias, J. M. Campistol, and J. M. Morales, "Late renal allograft failure between 1990 and 1998 in Spain: a changing scenario," Transplantation, vol. 76, no. 11, pp. 15881594, 2003.

[60] J. Torres, J. M. Aguado, R. San Juan et al., "Hepatitis C virus, an important risk factor for tuberculosis in immunocompromised: experience with kidney transplantation," Transplant International, vol. 21, no. 9, pp. 873-878, 2008.

[61] P. Burra, A. Buda, U. Livi et al., "Occurrence of post-transplant lymphoproliferative disorders among over thousand adult recipients: any role for hepatitis C infection?" European Journal of Gastroenterology and Hepatology, vol. 18, no. 10, pp. 1065-1070, 2006.

[62] J. M. Morales, J. M. Campistol, G. Castellano et al., “Transplantation of kidneys from donors with hepatitis C antibody into recipients with pre-transplantation anti-HCV," Kidney International, vol. 47, no. 1, pp. 236-240, 1995.

[63] S. Caillard, L. Y. Agodoa, E. M. Bohen, and K. C. Abbott, "Myeloma, Hodgkin disease, and lymphoid leukemia after renal transplantation: characteristics, risk factors and prognosis," Transplantation, vol. 81, no. 6, pp. 888-895, 2006.

[64] G. A. Knoll, M. R. Tankersley, J. Y. Lee, B. A. Julian, and J. J. Curtis, "The impact of renal transplantation on survival in hepatitis C-positive end-stage renal disease patients," American Journal of Kidney Diseases, vol. 29, no. 4, pp. 608614, 1997.

[65] K. C. Abbott, K. L. Lentine, J. R. Bucci, L. Y. Agodoa, T. G. Peters, and M. A. Schnitzler, "The impact of transplantation with deceased donor hepatitis C-positive kidneys on survival in wait-listed long-term dialysis patients," American Journal of Transplantation, vol. 4, no. 12, pp. 2032-2037, 2004.

[66] M. K. Breitenfeldt, J. Rasenack, H. Berthold et al., "Impact of hepatitis B and $\mathrm{C}$ on graft loss and mortality of patients after kidney transplantation," Clinical Transplantation, vol. 16, no. 2, pp. 130-136, 2002.

[67] H. Meier-Kriesche, A. O. Ojo, J. A. Hanson, and B. Kaplan, "Hepatitis C antibody status and outcomes in renal transplant recipients," Transplantation, vol. 72, no. 2, pp. 241-244, 2001. 
[68] F. L. Luan, D. E. Schaubel, H. Zhang et al., "Impact of immunosuppressive regimen on survival of kidney transplant recipients with hepatitis C," Transplantation, vol. 85, no. 11, pp. 1601-1606, 2008.

[69] K. Watashi, M. Hijikata, M. Hosaka, M. Yamaji, and K. Shimotohno, "Cyclosporin A suppresses replication of hepatitis $\mathrm{C}$ virus genome in cultured hepatocytes," Hepatology, vol. 38, no. 5, pp. 1282-1288, 2003.

[70] I. M. Mahmoud, M. A. Sobh, A. F. El-Habashi et al., "Interferon therapy in hemodialysis patients with chronic hepatitis C: study of tolerance, efficacy and post-transplantation course," Nephron Clinical Practice, vol. 100, no. 4, pp. c133c139, 2005.

[71] I. M. Mahmoud, A. F. Elhabashi, E. Elsawy, A. A. El-Husseini, G. E. Sheha, and M. A. Sobh, "The impact of hepatitis C virus viremia on renal graft and patient survival: a 9-Year prospective study," American Journal of Kidney Diseases, vol. 43, no. 1, pp. 131-139, 2004.

[72] F. G. Cosio, Z. Roche, A. Agarwal, M. E. Falkenhain, D. D. Sedmak, and R. M. Ferguson, "Prevalence of hepatitis C in patients with idiopathic glomerulopathies in native and transplant kidneys," American Journal of Kidney Diseases, vol. 28, no. 5, pp. 752-758, 1996.

[73] J. M. Morales, J. M. Campistol, A. Andrés, and J. L. Rodicio, "Glomerular diseases in patients with hepatitis C virus infection after renal transplantation," Current Opinion in Nephrology and Hypertension, vol. 6, no. 6, pp. 511-515, 1997.

[74] B. Domínguez-Gil, N. Esforzado, J. M. Campistol, A. Andrés, and J. M. Morales, "Use of hepatitis C-positive donors for kidney transplantation," Transplantation Reviews, vol. 21, no. 4, pp. 195-203, 2007.

[75] G. Basse, D. Ribes, N. Kamar et al., "Rituximab therapy for mixed cryoglobulinemia in seven renal transplant patients," Transplantation Proceedings, vol. 38, no. 7, pp. 2308-2310, 2006. 


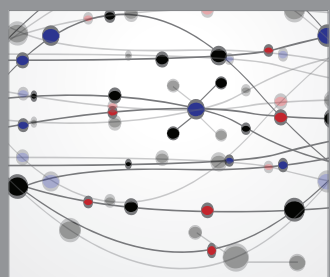

The Scientific World Journal
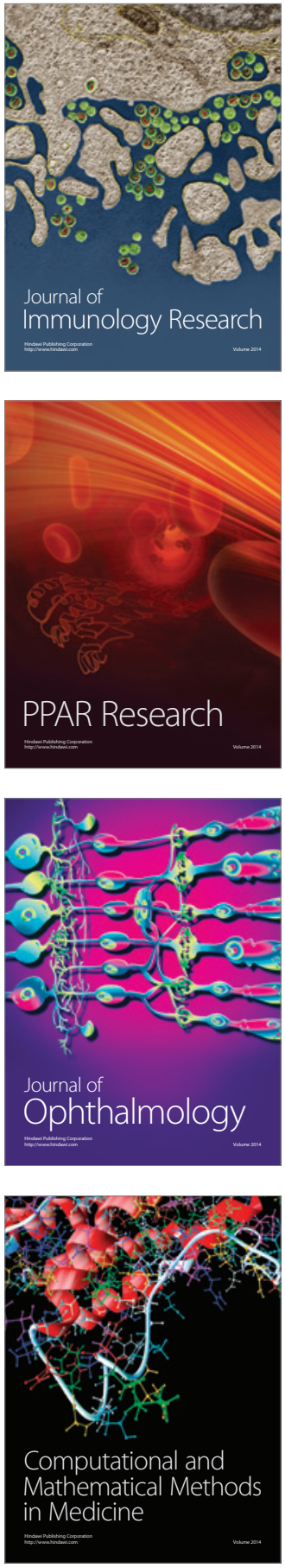

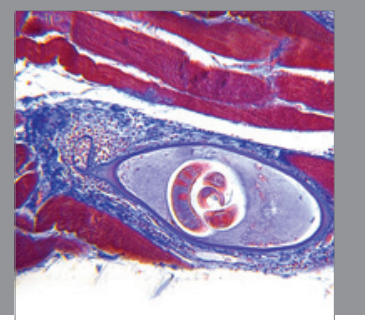

Gastroenterology

Research and Practice
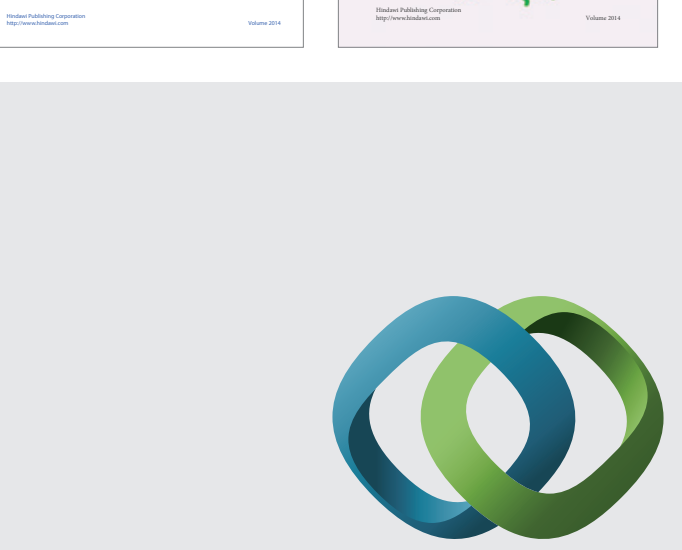

\section{Hindawi}

Submit your manuscripts at

http://www.hindawi.com
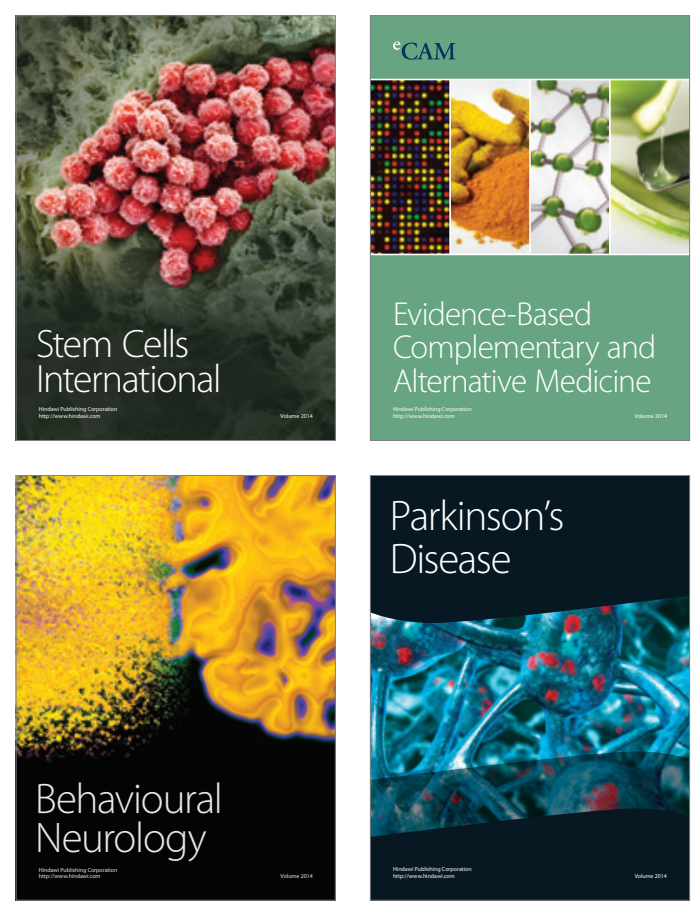

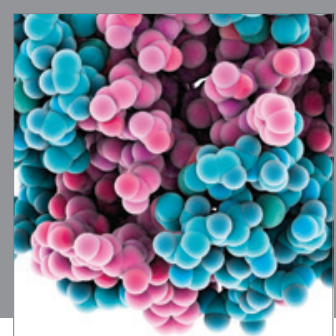

Journal of
Diabetes Research

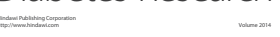

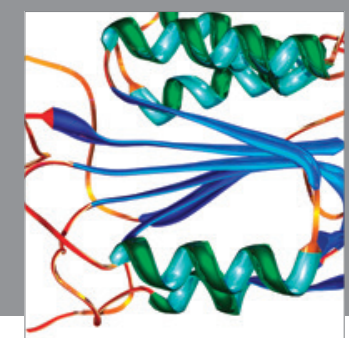

Disease Markers
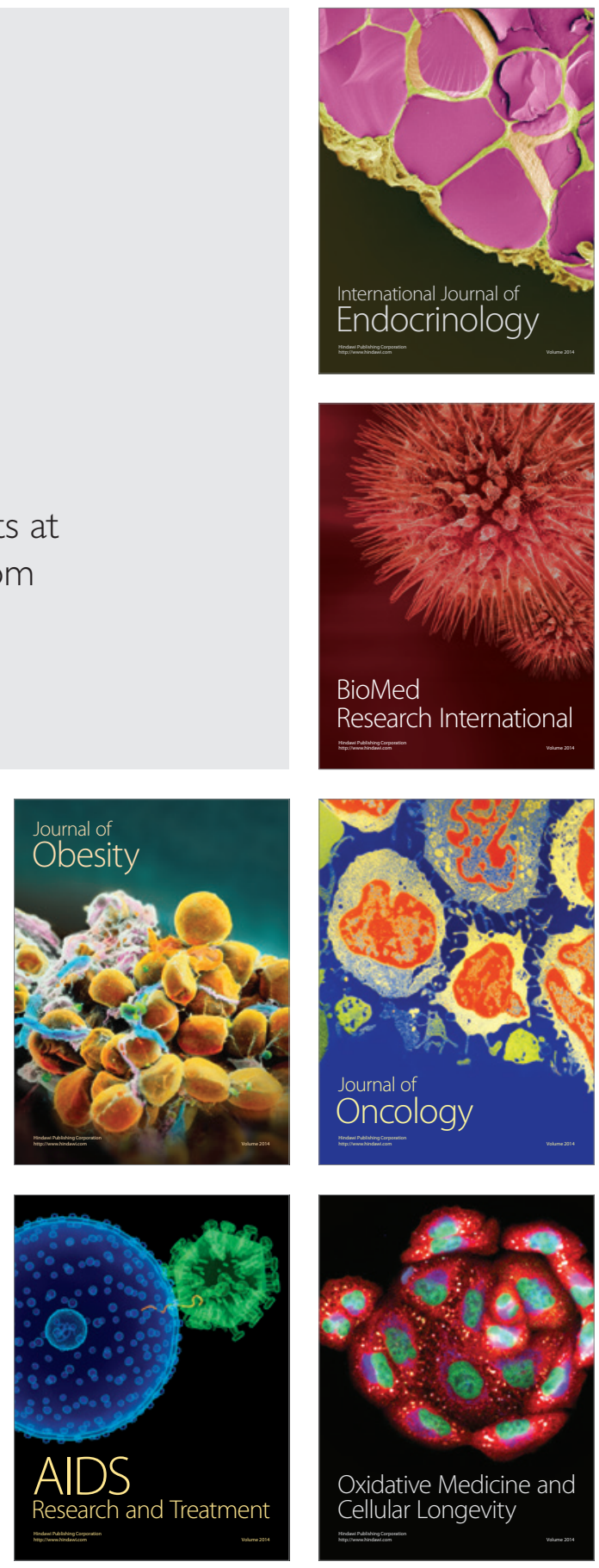